\title{
Brazil nuts a non-timber potential: Uncertainties and investments
}

\author{
Castanha do Brasil um potencial não madeireiro: Incertezas e investimentos \\ Castaña del Brasil un potencial no maderero: Incertidumbres e inversiones
}

Received: 10/16/2021 | Reviewed: 10/23/2021 | Accept: 11/11/2021| Published: 11/15/2021

Lyvia Julienne Sousa Rêgo

ORCID: https://orcid.org/0000-0001-7043-6860 Universidade Federal do Sul da Bahia, Brazil E-mail: lyvia.rego@ufsb.edu.br

Naisy Silva Soares

ORCID: https://orcid.org/0000-0001-6855-0218 Universidade Estadual de Santa Cruz, Brazil E-mail: naisysilva@yahoo.com.br

Crismeire Isbaex

ORCID: https://orcid.org/0000-0002-5909-7068 Universidade Federal de Viçosa, Brazil E-mail: engisbaex@gmail.com

Simone Silva

ORCID: https://orcid.org/0000-0002-0439-5009 Universidade Federal de Viçosa, Brazil E-mail: simone.silva.ufv@gmail.com

José Cola Zanuncio

ORCID: https://orcid.org/0000-0003-2026-281X Universidade Federal de Viçosa, Brazil E-mail: zanuncio@ufv.br

Márcio Lopes da Silva

ORCID: https://orcid.org/0000-0002-6742-4479 Universidade Federal de Viçosa, Brazil E-mail: marlosil@ufv.br

Flora Magdaline Benitez Romero

ORCID: https://orcid.org/0000-0001-9417-1780

Instituto Nacional de Pesquisas da Amazônia, Brazil E-mail: magdaline.romero@inpa.gov.br

\begin{abstract}
The Brazil nut is one of the main non-timber forest products in Brazil, but its price fluctuations generate uncertainties and risks for both extractivists and investors. Econometric models or other simpler methods can estimate price changes and indicate the investment attractiveness of the Brazil nut. The objective of the present study was to analyze the risk-return relationship and the export price for both volatility of the Brazil nut over a 15 years period. The historical series of Brazil nut export prices, shelled and unshelled nuts, was evaluated from 2002 to 2016. The geometric growth rate and the variation coefficient indicate the return and risk respectively, associated with its price series. The price volatility of shelled and unshelled Brazil nuts was estimated with the standard deviation of the price series and with generalized models of ARCH (GARCH, EGARCH and TARCH). The shelled or unshelled Brazil nut coefficient increased over 15 years, with a low risk-return ratio. The shelled Brazil nut volatility was lower in the 2002 to 2006, 2007 to 2011 and 2012 to 2016 periods than for the unshelled nut when estimated by the standard deviation method than for the unshelled nut. The shelled Brazil nut price was higher from 2002 to 2016, with low volatility and persistent shocks. The estimate of the shelled and unshelled Brazil nut price volatility was better with the TARCH and the EGARCH models, respectively.
\end{abstract}

Keywords: Investment; Attractiveness; Non-timber forest product; Volatility; Price.

\section{Resumo}

A castanha do Brasil é um dos principais produtos florestais não madeireiros do Brasil, mas as oscilações de preços geram incertezas e riscos para extrativistas e investidores. Modelos econométricos ou outros métodos mais simples podem estimar mudanças de preço e indicar a atratividade de investimento da castanha do Brasil. O objetivo do presente estudo foi analisar a relação risco-retorno e o preço de exportação para a volatilidade da castanha do Brasil em um período de 15 anos. As séries históricas dos preços de exportação da castanha do Brasil com e sem casca foram avaliadas de 2002 a 2016. A taxa de crescimento geométrico e o coeficiente de variação indicam o retorno e o risco respectivamente, associados à sua série de preços. A volatilidade dos preços da castanha do Brasil com e sem casca foi estimada com o desvio padrão das séries de preços e com modelos generalizados de ARCH (GARCH, EGARCH e TARCH). O coeficiente da castanha-do-brasil com ou sem casca aumentou em 15 anos, com baixa 
relação risco-retorno. A volatilidade da castanha do Brasil com casca foi menor nos períodos de 2002 a 2006,2007 a 2011 e 2012 a 2016 do que para a castanha sem casca quando estimada pelo método do desvio padrão do que para a castanha sem casca. O preço da castanha do Brasil descascada foi mais elevado de 2002 a 2016, com baixa volatilidade e choques persistentes. A estimativa da volatilidade do preço da castanha do Brasil descascada e descascada foi melhor com os modelos TARCH e EGARCH, respectivamente.

Palavras-chave: Investimento; Atratividade; Produto florestal não madeireiro; Volatilidade; Preço.

\section{Resumen}

La castaña es uno de los principales productos forestales no maderables en Brasil, pero sus fluctuaciones de precios generan incertidumbres y riesgos tanto para los extractivistas como para los inversionistas. Los modelos econométricos u otros métodos más simples pueden estimar cambios de precios e indicar el atractivo de inversión de la castaña. El objetivo del presente estudio fue analizar la relación riesgo-rendimiento y el precio de exportación de ambos la volatilidad de la castaña en un período de 15 años. La serie histórica de precios de exportación de nueces de Brasil, nueces sin cáscara y sin cáscara, se evaluó de 2002 a 2016. La tasa de crecimiento geométrico y el coeficiente de variación indican el rendimiento y el riesgo, respectivamente, asociados con su serie de precios. La volatilidad de los precios de las castañas con y sin cáscara se estimó con la desviación estándar de la serie de precios y con modelos generalizados de ARCH (GARCH, EGARCH y TARCH). El coeficiente de nueces de Brasil sin cáscara o sin cáscara aumentó durante 15 años, con una baja relación riesgo-rendimiento. La volatilidad de la nuez de Brasil sin cáscara fue menor en los períodos 2002 a 2006, 2007 a 2011 y 2012 a 2016 que para la nuez sin cáscara cuando se estimó mediante el método de desviación estándar que para la nuez sin cáscara. El precio de la nuez de Brasil sin cáscara fue más alto de 2002 a 2016, con baja volatilidad y shocks persistentes. La estimación de la volatilidad de los precios de la nuez de Brasil sin cáscara y sin cáscara fue mejor con los modelos TARCH y EGARCH, respectivamente.

Palabras clave: Inversión; Atractivo; Producto forestal no maderable; Volatilidad; Precios.

\section{Introduction}

The collection of economic products in the Amazonian forest allows direct and cheap access to non-timber forest products (NTFPs), including the products of extractivism activities such as fibers, fruits, nuts, oils and rubber (Goeschl \& Igliori, 2006). The commercial extraction of Brazil nuts in the Amazon is a subsistence strategy to diversify the dependence on rubber production, mainly in the context of a worsening scenario for this commodity in the international market (Stoin, 2000,2005). The Brazil nut is one of the most important NTFPs in the Amazonian region (Stoian \& Henkemans, 2000; Scoles $\&$ Gribel, 2011), harvested mainly in native forests (Helbingen, 2001; Zuidema, 2003), because planted trees only start fruit production when they are over eight years old (Costa et al., 2009).

In 2015, Brazilian forest production totaled R\$ 18.4 billion, of which 9.7\% were NTFPs with R\$ 1.5 billion from plant extractive activity and R 292.9 million from silviculture. Vegetable extraction in northern Brazil is characterized by products such as açaí and Brazil nuts, with the latter reaching R\$107.4 million in 2015 (IBGE, 2017) with US\$ 15.1 million exported in 2016 (MDIC consultas, 2021). Bolivia (Bayna et al., 2014), USA (Collinson et al., 2000; Yang, 2009; Reis et al., 2014), China, Peru, the European Union (Bayna et al., 2014), Australia, Canada, Japan and Vietnam (Pacheco, 2009) were the largest buyers of Brazil nuts.

Brazil nuts usually receive little processing (Pacheco, 2009)]. The Brazilian Ministry of Agriculture, Livestock and Food Supply, standardized the domestic commercialization of unshelled nuts (natural, cleaned, and dried either naturally or by adequate dehydration) and shelled nuts with value added (cleaned and dried, with the removal of shells) (MAPA, 1976).

The market of Brazil nuts and other Brazilian NTFPs, with a large increase from 2000 to 2010 (Schirigatti et al., 2016), are competitive in the world. The Brazil nut has a low degree of trade opening (Soares \& Silva, 2010), but the value exported grew 1.7\% per year from 2002 to 2016(MDIC consultas, 2021), evidencing its importance for Brazil and reaching other markets (Soares \& Silva, 2010).

Brazil's competitiveness in the international trade of Brazil nuts has declined and Bolivia and Peru are presently the leading suppliers worldwide (Stoian, 2000; Coslovsky, 2014; FAO, 2021). The international market for this commodity is well established (Kalliola \& Flores, 2011), and with the amount that their main world buyers want to pay for the Brazil nut and the 
possible threats to its harvest in the Amazon can be minimized to making it economically and ecologically sustainable (Silvertown, 2004).

Variables such as international price (Soriano et al., 2017), exchange rate variations (Dwyer et al., 2000; Siggel, 2000), profitability and others (Buckley et al., 1988) affect Brazil nut prices (Angelo et al., 2013) and the expansion of this activity. However, the informal nature of commercials transactions (Brokamp et al., 2011; Shanley et al., 2012) complicated the trade in NTFPs, for example, in Cameroon, where up to 30\% of the harvest of fruits is exchanged as barter or cultural gift (Ingram et al., 2012). Beyond, market price determination for NTFPs that sellers use is by an informal mechanism (Mugido $e t$ al., 2018) and the official data for some NTFPs to be non-existent or inconsistent, as in the case of the European countries trade (Turtiainen \& Nuutinen, 2012).

The volatility of market prices and the global pressures to deforest the Amazon exacerbate the fragility of the Brazil nut economy (Kalliola \& Flores, 2011). Volatility generates investment uncertainties, risk management requirements and monetary policy (Sabiruzzaman et al., 2010) for extractivists and investors in the Brazil nut market. Models such as the generalized ARCH (Koutmos \& Booth, 1995; Andersen et al., 2001; Silva \& Ferreira, 2015) can adjust the irregular variation of price using a time series (Hansen \& Lunde, 2005). Reliability and investment decisions increase with declining volatility with an inverse relationship to investor confidence (Jubert et al., 2008).

Price dynamics and yields affect investment risk and return (Geltner \& Van De Minne, 2017), which are often evaluated using regression statistics (Barak et al., 2017).

The future behavior of the export price variation of the Brazil nut and its risk-return relationship needs further studies to help producer investment decisions and public policy-making for this product. The objective of this present study was to estimate the risk-return relationship and the export price volatility of Brazil nuts over a fifteen-year period.

\section{Methodology}

\subsection{Data source}

This is a quantitative study, as we structured a database and statistical analysis. The information was obtained from secondary data collected from the Foreign Trade information analysis system (Comex Stat) of the Brazilian Ministry of Development, Industry and Foreign Trade (MDIC consultas, 2021). The monthly historical series of both shelled and unshelled Brazil nut export prices were obtained by dividing the FOB (Free on Board) value of exports in dollars by the total product weight exported amount in kilograms from January 2002 to December 2016 with 180 observations. The prices have not been corrected for inflation.

The behavior of annual prices and historical volatility series, calculated for standard deviation, were analyzed from 2002 to 2016 and separated into three periods of five years each (2002 to 2006, 2007 to 2011 and 2012 to 2016). Volatility, for the period from 2002 to 2016, was calculated using generalized ARCH models. Differences between product price averages were evaluated with the $t$ test at a $5 \%$ significance level.

The price series for the shelled Brazil nuts showed a steady trend and, for this reason, were transformed into return series (Morettin \& Toloi, 2006), replacing the original ones. The return was obtained with the price logarithm and the first difference using the formula:

$$
\mathrm{r}_{t}=\ln \left(\mathrm{P}_{t}\right)-\ln \left(\mathrm{P}_{t-1}\right)
$$

where: $\mathrm{r}_{t}$ is the return of the period $t-1 ; \mathrm{P}_{t}$ the price in the period $t ; \mathrm{P}_{t-1}$ the price in the period $t-1$ (Morettin \& Toloi, 2006). 


\subsection{Risk and return}

The relationship between risk and return was determined by the Geometric Growth Rate (GGR) and variation coefficient, representing the expected return and risk, respectively, associated with the historical series of each product, by linear regression analysis of the trend:

$$
\log Y=a+b \mathrm{~T}
$$

where: $\mathrm{Y}$ is the price in Reais; $\mathrm{T}$ the trend in months; $a, b$ regression parameters.

The geometric growth rate with non-zero values of b at a $95 \%$ probability level was calculated by AntLogb= $1+G G R$, where GGR $=($ AntLogb-1) $\times 100$.

\subsection{Volatility}

The price and return series of Brazil nuts were treated by descriptive statistics such as mean, median, standard deviation, asymmetry and kurtosis, normality and stationarity tests prior to using ARCH models to understand the price volatility. The normality of the series was submitted to the Jarque-Bera test. The stationarity of the series was submitted to the Augmented Dickey Fuller (ADF) test to verify the presence or absence of unitary roots in the series. The presence of autoregressive conditional heteroscedasticity or of $\mathrm{ARCH}$ pattern volatility in the series was evaluated using the Lagrange Multiplier (LM) (Engle, 1982).

The volatility of the temporal historical series of Brazil nut prices during the different periods was calculated with equation (1) (Purcell \& Koontz, 1999):

$$
\left.\sigma=\left(\left(\ln \left(\mathrm{P}_{t} / \mathrm{P}_{t-1}\right)-\mu\right)^{2} / n-1\right)^{*} m\right)^{1 / 2}
$$

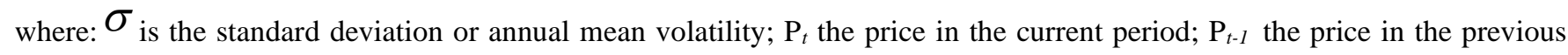

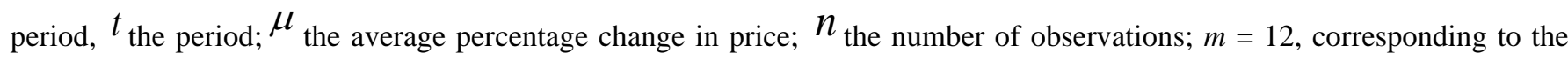
months of the year.

Brazil nut price volatility was estimated using the GARCH (Generalized Autoregressive Conditional Heteroskedasticity); EGARCH (Exponencial Generalized Autoregressive Conditional Heteroskedasticity) and TARCH (Threshold Autoregressive Conditional Heteroskedasticity), models variants of the original ARCH (Autoregressive Models with Heteroscedasticity), because they have a more complex structure and predictive capacity than simpler ones (Santos, 2003; Marius, 2012).

The ARCH model [43] assumes that the volatility of a time series is the variance of " $\varepsilon$ " at once $t$ dependent on the square of the error in the previous period, that is, $\varepsilon_{t-1}^{2}, \ldots \varepsilon_{t-\mathrm{p}}^{2}$.

The ARCH model is expressed as:

$$
\sigma^{2}=\alpha_{0}+\alpha_{l} \varepsilon_{t-\mathrm{p}}^{2}+\ldots+\alpha_{p} \varepsilon_{t-\mathrm{p}}^{2}
$$

where: $\sigma_{t}^{2}$ is the conditional variance, $\alpha_{0}$ the constant; $\alpha_{l}$ the coefficient of reaction associated with $\varepsilon_{t-\mathrm{i}}^{2}, i=1, \ldots, \mathrm{p}, \varepsilon_{t-\mathrm{p}}^{2}$ is a heteroscedastic error term out of date; $\alpha_{p} \varepsilon_{t \text {-p }}^{2}$ the reaction coefficient followed by n nulls included in the model. 
The constraints imposed in the model are that the conditional variance is positive and that $\alpha_{0}>0$ and $0<\alpha_{1}<1$.

The GARCH model volatility was defined by the model:

$$
\sigma_{\mathrm{t}}^{2}=\alpha_{0}+\alpha_{l} \varepsilon_{t-1}^{2}+\beta_{l} \sigma_{t-1}^{2}
$$

where: $\sigma_{\mathrm{t}}^{2}$ is the conditional variance during the period $t ; \alpha_{0}$ the constant; $\alpha_{l}$ the volatility reaction coefficient; $\varepsilon_{t-1}^{2}$ the error term squared in a period; $\beta_{1}$ the coefficient of persistence of volatility; $\sigma_{t-1}^{2}$ the devalued conditional variance of a period.

The conditions for conditional variance to be positive and stationary are: $\alpha_{0}>0$ and $\alpha_{i} \geq 0$, for $i=1, \ldots \mathrm{p} ; \beta j \geq 0$, for $j=$ $1, \ldots \mathrm{q} ; \sum_{i=1}^{p} \alpha_{i}+\sum_{j=1}^{q} \beta_{i}<1$.

The coefficient $\alpha$ measures the extent of an impact in the present series on future volatility. High $\beta \mathrm{j}$ coefficient values indicate that the shocks of conditional variance take longer to be completely dissipate (Silva, 2009).

The sum of $\alpha_{i}+\beta_{i}$ measures the persistence of price volatility shocks and the return series for the Brazil nut. The sum of these parameters near zero indicates the initial shock effects on short-term volatility and the behavior of the series and, thereafter, that the series variance converges toward a historical average.

The asymmetric distribution problem was incorporated by the EGARCH and TARCH models. The conditional variance was defined in the EGARCH model by Nelson (1991):

$$
\ln \left(\sigma_{t}^{2}\right)=\alpha_{0}+\alpha_{I}\left(\left|\varepsilon_{t-1} / \alpha_{\mathrm{t}-1}\right|\right)+\beta_{1} \ln \left(\sigma_{t-1}^{2}\right)+\gamma_{l}\left(\varepsilon_{t-1} / \alpha_{t-1}\right)
$$

where: $\ln \left(\sigma_{t}^{2}\right)$ is the natural logarithm of the conditional variance in the period $t ; \alpha_{0}$ the constant; $\beta_{1}$ the coefficient of persistence of volatility; $\ln \left(\sigma_{t-1}^{2}\right)$ the natural logarithm of the conditional variance raised to the squared stage in a period; $\alpha_{1}$ the volatility reaction coefficient; $\varepsilon_{t-1}$ the error elapsed in a period; $\gamma_{1}$ the coefficient that captures the asymmetry effect of volatility.

A zero value for the $\gamma_{I}$ coefficient indicates a lack of asymmetry, and if different from zero a differential impact of negative and positive shocks on volatility. When $\gamma_{1}<0$, it indicates a leverage effect, when this coefficient is greater than 1 , a positive shock reducing series volatility is indicated.

TARCH is a nonlinear ARCH model with the conditional variance described by:

$$
\sigma^{2}=\alpha_{0}+\alpha_{l} \varepsilon_{t-1}^{2}+\gamma_{l} \mathrm{~d}_{\mathrm{t}-1} \varepsilon_{t-1}^{2}+\beta_{l} \sigma_{t-1}^{2}
$$

where: $\sigma_{t}^{2}$ is the conditional variance in the period $t ; \alpha_{0}$ the constant; $\alpha_{l}$ the volatility reaction coefficient; $\varepsilon_{t-1}^{2}$ the error term squared in a period; $\gamma_{l}$ the asymmetric effect on volatility; $\mathrm{d}_{t-1}$ the dummy variable; $\beta_{1}$ the coefficient of persistence of volatility; $\sigma_{t-1}^{2}$ the devalued conditional variance of a period (Zakoian, 1994).

This model has the same assumptions as EGARCH, differentiating by the inclusion of the dummy variable $d_{\mathrm{t}-1}$, where a value equal to one of $\varepsilon_{t-1}^{2}<0$ shows a negative shock effect (bad news on the market).

The model with the best fit in the "Brazil nuts (shelled or not) series" was the one with the lowest values of the Akaike and Bayesian selection criteria. The regression of data and analysis models were estimated using the Eviews 7.0 software. 


\section{Results}

\subsection{Export price of Brazil nuts from 2002 to 2016}

The average export prices of shelled or unshelled Brazil nuts differed from 2002 to 2016. The price trends during this period increased by $0.3 \%$ and $0.8 \%$ ( $\mathrm{p}<0.01$ ) for unshelled and shelled nuts, respectively. The unshelled nut price was similar in the periods 2004 to 2006 and 2013 to 2014. It increased from 2004 until 2008, dropped in 2009, increased until 2012, dropped again and reached the highest price in 2016 that in the rest of the period. The shelled nut price was low in the first two years, increased until 2005, remained constant from 2006 to 2008 and increased from 2009 to 2011. The price was highest from 2011, but it moderately dropped in 2012 and 2013 (Figure 1).

The average price $\left(\mathrm{kg}^{-1}\right)$ of unshelled nuts had lower variation, from US\$ 0.96 to 2.33 , than that for the shelled ones, from US\$ 2.05 to 12.02. The annual shelled nut price varied from -27\% (2011-2012) to 75\% (2010-2011) and those of unshelled from $-32 \%$ (2012-2013) to $90 \%$ (2015-2016). The symmetry periods in the nut prices were from 2002 to 2003 , 2007 to 2011,2012 to 2013 and from 2014 to 2016. In 2016, the price of shelled nut was 3.8 times greater than that of unshelled ones (Figure 1).

Figure 1. Export price (average and standard error) of shelled (a) and unshelled (b) (dollars per kilo) Brazil nuts from 2002 to 2016.
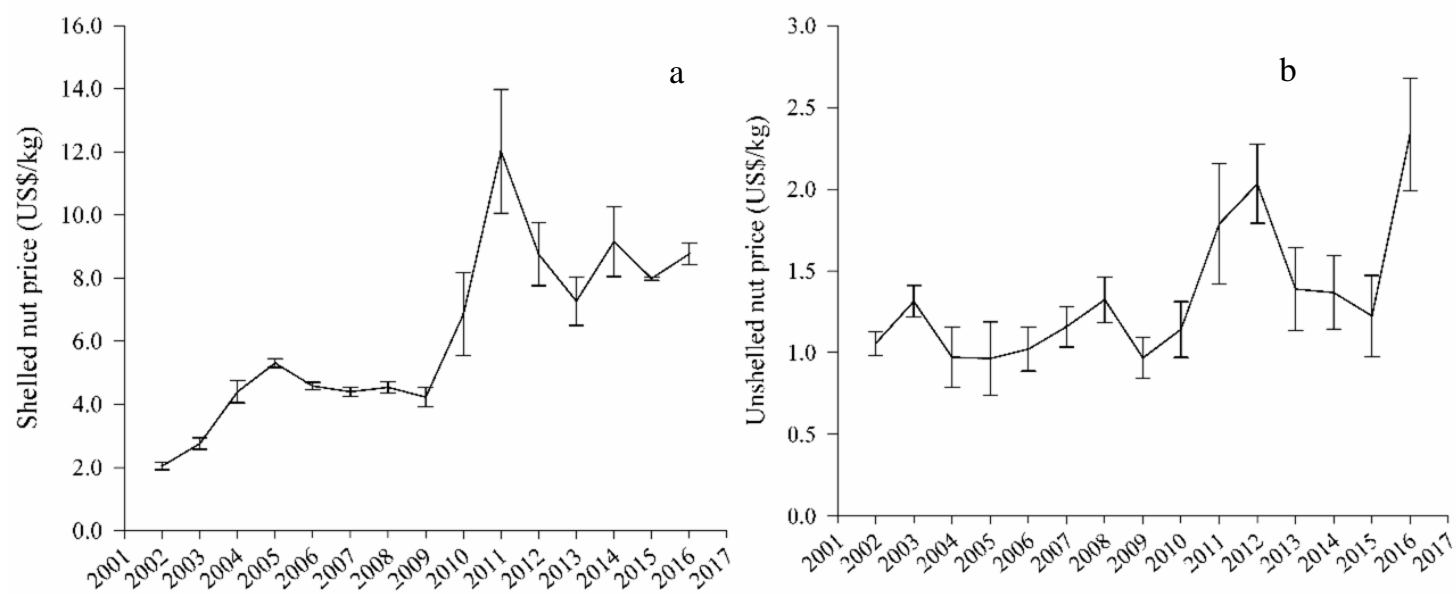

Source: Own elaboration.

\subsection{Risk return ratio}

The risk to return ratio of Brazil nuts was low from 2002 to 2016 with positive rates for both shelled and unshelled nuts. Shelled nut returns were higher (0.75) and its risk (0.60) lower than those of unshelled ones with values of 0.33 and 0.61 , respectively, making it more attractive for investors. The risk-return ratio of the shelled nut was consistent between $2002-2006$ and 2007-2011 with 1.61 return and 0.73 risks, when it had positive values of risks return, with 2002-2006 having the highest return (2.0) and lowest risk (0.36) expectative.

The $b$ parameter of the geometric rate equation for unshelled nuts in the periods from 2002 to 2006, 2007 to 2011 and 2012 to 2016 was not significant ( $>$ > 0.05), making it impossible to obtain and compare the risks of this producing those periods. 


\subsection{Volatility}

The volatility in the price of unshelled Brazil nuts was low (less than 3\%), and lower than that of unshelled, except from 2007 to 2011, where it was more volatility. On the other hand, nut with shell (Unshelled Brazil nut) was less volatility in this five-year period, increasing from 4.48 to 6.72 in the following period, with the highest price volatility of this product. The price volatility of shelled shell was lower in the first five-year period (2002-2006).

Table 1. Average volatility percentage and standard deviation of annual prices of Brazil nuts (US\$/kg) from 2002 to 2016.

\begin{tabular}{|c|c|c|}
\hline Period & Unshelled Brazil nut & Shelled Brazil nut \\
\hline $2002-2006$ & $6.53 \pm 0.24$ & $1.12 \pm 0.05$ \\
\hline $2007-2011$ & $4.48 \pm 0.22$ & $10.51 \pm 0.25$ \\
\hline $2012-2016$ & $6.72 \pm 0.24$ & $1.31 \pm 0.12$ \\
\hline $2002-2016$ & $3.32 \pm 0.13$ & $2.37 \pm 0.09$ \\
\hline
\end{tabular}

Source: Authors.

The return and price series of Brazil nuts were asymmetrically positive, with the average higher than the median. The positive asymmetry coefficients indicate distribution with longer tails to the right. The series distribution is leptokurtic with high kurtosis values ("flattening" degree of the distribution curve) for the return series of the shelled Brazil nut with a distribution function curve more tapered and concentrated than the normal one. The series did not follow a normal distribution according to the Jarque-Bera test and, therefore, the null hypothesis of the residues normality was rejected (Table 2).

Table 2. Descriptive statistics of the return price series for shelled and unshelled Brazil nuts from 2002 to 2016.

\begin{tabular}{|c|c|c|}
\hline Statistic & Unshelled Brazil nut & Shelled Brazil nut \\
\hline Mean & 1.3367 & 0.0102 \\
\hline Median & 1.1928 & 0.0050 \\
\hline Standard deviation & 0.8140 & -1.2651 \\
\hline Asymmetry & 1.3504 & 38.9641 \\
\hline Kurtosis & 5.2655 & 9694.4490 \\
\hline Jarque-Bera (JB) test & 93.2012 & $<0.0001$ \\
\hline P-valor test JB & $<0.0001$ & 179 \\
\hline Observations & 180 & \\
\hline
\end{tabular}

Source: Authors.

The price and return series for unshelled and unshelled Brazil nuts, respectively, showed signs of heteroscedasticity with stationarity at the level for the one with the shell and at first difference for the one without the shell. Thus, both series did not have a unit root, as the values of the ADF test were greater than the critical values at 5\%, rejecting the null hypothesis of unit root (H0), in addition, the p-value was less than 0.05 , being tolerable by the statistical method (Table 3 ). 
Table 3. Statistical test (ADF) and critical value (5\%) for the price series of unshelled Brazil nut and for the return series of shelled Brazil nut, from 2002 to 2016.

\begin{tabular}{|c|c|c|c|}
\hline Variable & Statistic & ADF test & Critical value \\
\hline \multirow{3}{*}{$\begin{array}{c}\text { Price series of unshelled Brazil } \\
\text { nut }\end{array}$} & With intercept and trend & -6.8479 & -2.8775 \\
\cline { 2 - 4 } & With intercept and no trend & -7.3352 & -3.4351 \\
\cline { 2 - 4 } & No intercept and no trend & -3.1926 & -1.9426 \\
\hline $\begin{array}{c}\text { Return series } \\
\text { of shelled } \\
\text { Brazil nut }\end{array}$ & With intercept and trend & -21.0406 & -2.8776 \\
\cline { 2 - 4 } & With intercept and no trend & -20.9824 & -3.4353 \\
\hline
\end{tabular}

Source: Authors.

The GARCH model parameters, estimated for the return series for shelled Brazil nuts, are within the constraints, with consistent results, similar to each other at 5\%. The sum of parameters $\alpha_{1}$ and $\beta_{1}(0.93)$ close to one indicates that a volatility shock will persist for a long period with slow dissipation in relation to the unshelled nut series with the lowest value of this sum (0.6). The persistence parameter indicated that $71 \%$ of the shock generated in the previous period will persist in the present one (Table 4).

The parameter estimated by the EGARCH model, capturing the volatility (0.40) and significant at $1 \%$, confirms the asymmetry in the return volatility of the shelled nuts, but without evidence of the leverage effect (Table 4). The other parameters of this model were also significant. Thus, the positive shocks have a greater impact on the price increases of the shelled nuts than the negative ones.

Table 4. Estimation of the parameters of the GARCH, EGARCH and TARCH models for price series of unshelled Brazil nuts (unshelled) and for the return series of shelled (She.) or unshelled (Uns.) Brazil nuts and from 2002 to 2016.

\begin{tabular}{|c|c|c|c|c|c|c|}
\hline \multirow{2}{*}{ Coefficient } & \multicolumn{2}{|c|}{ GARCH (1,1) } & \multicolumn{2}{c|}{ EGARCH (1,1) } & \multicolumn{2}{c|}{ TARCH (1,1) } \\
\cline { 2 - 6 } & Uns. & She. & Uns. & She. & Uns. & She. \\
\hline$\alpha_{0}$ & 0.1260 & 0.0076 & -1.5292 & -1.1636 & 0.0334 & 0.0029 \\
\hline$\alpha_{l} \varepsilon_{t-1}^{2}$ & 0.2866 & 0.2280 & & & 2.1611 & 2.5048 \\
\hline$\beta_{l} \sigma_{t-1}^{2}$ & 0.3232 & 0.7091 & & & 0.2332 & 0.5004 \\
\hline$\gamma_{I} \mathrm{~d}_{\mathrm{t}-1} \varepsilon_{t-1}^{2}$ & & & & & -1.6711 & -2.3697 \\
\hline$\alpha_{l}\left|\varepsilon_{t-1}\right| /\left|\sigma_{\mathrm{t}-1}\right|$ & & & 1.3509 & 1.0565 & & \\
\hline$\gamma_{l} \varepsilon_{\mathrm{t}-1} / \sigma_{\mathrm{t}-1}$ & & & 0.4166 & 0.4071 & & \\
\hline$\beta_{1} \ln \left(\sigma_{t-1}^{2}\right)$ & & & 0.5878 & 0.8548 & & \\
\hline Akaike $(\mathrm{AIC})$ & 1.8686 & 0.0065 & 1.9545 & -0.3462 & 1.5836 & -0.1718 \\
\hline Schwarz $(\mathrm{BIC})$ & 2.0668 & 0.1138 & 2.0432 & -0.2572 & 1.6904 & -0.2247 \\
\hline
\end{tabular}

Source: Authors.

The parameters estimated by the TARCH model for the shelled nut returns were significant at $1 \%$. This modeling also captured the shock asymmetry, with the negative ones affecting, more intensely, the price volatility in relation to the positive ones. A $\gamma_{I}$ parameter, lower than zero, identified the leverage effect. The persistence parameter $(0.5)$ indicated that a shock on the return volatility would remain for several periods (Table 4).

The persistence parameter of the GARCH adjustment, for the price volatility of unshelled Brazil nuts, indicated that $32 \%$ of the shock generated in the previous period would persist in the future, but only for a short period. The EGARCH model 
also showed asymmetry $(0.42)$ with significant estimated parameters at $1 \%$. The shock persistence in the volatility captured by this model (0.58) was superior to that of the GARCH (1.1) (Table 4).

The TARCH model (1.1) confirmed the asymmetry indicated by the EGARCH (1.1) in the price series of the unshelled nuts with the parameter associated with the dummy term, differing from zero. This value lower than zero (-1.67) confirms the leverage effect and shocks or negative information in this series rather than positive ones of the same magnitude. The TARCH parameters (1.1) were significant at $1 \%$ (Table 4).

The TARCH econometric model (1.1) had the best predictive performance for adjusting the price series volatility of the unshelled nuts, with lower AIC and BIC statistics. However, the parameters estimated by EGARCH (1.1) presented the best adjustment for the return series volatility.

\section{Discussion}

\subsection{Challenges of Brazil nut marketing}

In a general context, differences between unshelled and shelled Brazil nut prices may be associated with intermediate agents that control them (Collinson et al., 2000, Ahenkan \& Boon, 2010) in the extractivism economic system. The growing trend in the price of Brazil nuts was due to domestic income and the exchange rate increase from 2011 onwards, increasing demand and inflating the price. Deforestation reduces Brazil nut stock in the forest and longer harvesting distance increases its extraction cost and price (Angelo et al., 2013. In addition, NTFPs may be vulnerable to landscape changes such as agricultural or urban sprawl, habitat fragmentation, invasive species, burning and grazing, which threatens the ecological and economic sustainability of the NTFPs as a source of income and livelihood (Sardeshpande et al., 2019). Annual deforestation in the Legal Amazon from 2002 to 2016 tended to decrease by 11\%, but higher deforestation rate between 2002 to 2008 (INPE,2016) may have contributed to the Brazil nut price increase. This price increase may be related to reduced harvesting by extractivists, affecting the nut supply (Collinson et al., 2000). Failures in competitive Brazil nut harvests have led to increases in the local, national and international markets since 2003 (Duchelle et al., 2011), mainly in Europe (Belcher \& Schreckenberg). The angular parameter of the regression presented a non-significant value without meeting the statistical requirements and showed that those unshelled Brazil nut price were similar (Montgomery et al., 2012). The 2003 to 2006 increase in demand for shelled nuts was due to growing foreign buying (Pacheco \& Martins, 2013), reaching 10.5 thousand tons (MDIC consultas, 2021), especially in the food industry (Monteiro et al., 2016) for the organic food market (Reis et al., 2014). There is no speculative element causing large and unjustified price change in many commodities and the annual price tends to be cyclic (Collinson et al., 2000).

The marketing of in natura products explains the low variation in the export price of unshelled Brazil nuts, while the variation of the shelled ones was attributed to fruit and seed production due to exogenous and endogenous factors. The harvest size influences its price (Assies, 2016; Silva et al., 2013). Production depends on the climate, and its annual distribution patternsand precipitation, and/or other variables such as seasonal temperature are correlated (Kainer et al., 2007; Tonini \& Pedroza, 2014). The weather of the Amazon region, with high temperatures and rainfall, slows harvesting times and increases post-harvest losses. These effects decrease nut quality (Collinson et al., 2000) by favoring fungal growth, which reduces prices (Baquião et al., 2012), mainly of dry and shelled nuts (Scussel et al., 2011) stored to ensure supply throughout the year (Ahenkan \& Boon, 2010). Access to the largest number of trees, and proximity to both the commercialization center and the nut trees by the extractivists reduce transport costs and increases the income for the shelled nuts (Nelson et al., 2000). Nut buying, usually, in isolated or inaccessible areas, especially in indigenous villages (Ros-Tonen et al., 2008) allows high profit 
rates by those controlling most of the extractive production and, therefore, the final price (Silva et al., 2013). For these reasons, the price received by the extractivist tends to be low (Assies, 1999). In addition, local conditions and annual fluctuation in the demand (Baroi et al., 2017) and supply also impact the international nut price, a physical commodity at predetermined prices, but with seasonal demand and price variations (Collinson et al., 2000). Research cooperation and investment are alternatives to increase Brazil nut sales, profitability and cost savings. Public policy implementation and innovation are key elements for reducing risks and uncertainties and improving market competitiveness and performance, regardless of the size of the cooperative, association or company (Riguero et al., 2018) and the tradition of minimal cooperation in the agri-food sector (Rabadán et al., 2019).

The low risk/return ratio for Brazil nuts is mainly due to precarious infrastructure for transport and storage (Toledo et al., 2016). Nut producers are subject to a lack of programs and policies to encourage production, with low value-adding, and strict regulations by Brazilian agencies for commercialization in terms of traceability, quality control, transport mechanisms, sampling systems, selection of nuts, laboratory testing, etc. (Enriquez, 2010). The Brazilian federal legislation, which prohibits the cutting of Brazil nut trees (Decree n. 5.975 of 2006) is the main legal instrument that encourages the conservation of the species, which allows only the use of non-timber resources of regional economic importance (Duchelle et al., 2011; Shanley et al., 2012). The Portaria of MAPA no. 846 of 1976 lists the specifications for the standardization, classification and internal marketing of Brazil nuts. Public agencies have normative instruments and guidelines that promote the use of forest resources through good practices in handling Brazil nuts. The Minimum Price Guarantee Policy and the Food Acquisition Program is one of the public policies created to strengthen the sustainable extractive practice (Brasil, 2017). In the state level, some laws support families to manage forest resources, as in the Amazonian states of Amapá, Acre, Pará and Amazonas (Shanley et al., 2012). For example, in the state of Amazonas, the specific law on Brazil nuts that extractive producers can access are Decree $n$. 25,275 of 2005 and Law no. 2,611 of 2000 (Brasil, 2017). However, political efforts with laws aiming to protect Brazil nuts are ineffective due to failures in implementation and obstacles (Homma et al., 2001). Such conditions discourage extractivists and producers, compromise the stock of this raw material (Brasil, 2017), and consequently export, reducing their economic returns.

Low exchange rates (Angelo et al., 2013), unexapected price fluctuations and high interest rates are uncertainties in the forest sector (Andersson \& Gong, 2010). The risk/return ratio on the price of other forest products such as the timber of Hymenolobium nitidum Benth, Dinizia excelsa Ducke), Tabebuia spp., Handroanthus spp., Hymenaea spp. and Manilkara spp., native to Amazonia, showed a consistent ratio with Hymenaea spp., being more attractive with higher returns than risks (Noce et al., 2010). The dynamics of agri-food sector competitiveness in five Central European countries (CE-5) verified that bulk raw products are subject to higher risk increase compared to processed products because these have greater competitiveness and commercial advantages (Bojnec \& Fertö, 2012).

In this study, the lack of growth in the unshelled nut prices may be associated with parameter $b$, since its lack of significance in the Geometric Growth Rate equation, indicated that the price of unshelled Brazil nuts did not present a linear growth trend over the period. The significance of $b$ greater than $10 \%$ increases the likelihood of error by stating that the geometric growth rate differs from zero (Andersson \& Gong, 2010). Thus, the lack in growth trend in the unshelled nut price is due to the fact that it is a forest product with no value added without benefited. Therefore, its price is less sensitive to the fluctuations of production inputs (Sathre \& Gustavsson, 2009), and of individual variables, such as materials/supplies, energy, labor and capital cost (Lantz, 2005). 


\subsection{Analysis of volatility models}

The low volatility of shelled Brazil nuts price from 2002 to 2006 reflected the interest rate risk and the depreciated Brazilian currency. This shows that exporters take advantage of increased exchange rate volatility and respond quickly to a larger export supply in a manner similar to that reported in Thailand's commodity trade (Langley et al., 2000). The greater price volatility of the shelled nut from 2007 to 2011 was due to the floating exchange rate with a minimum of R $\$$ US\$ 1.66 and a maximum of R $\$ / U S \$ 2.50$ in 2008 (BCB, 2017).

The positive asymmetric distribution of Brazil nut returns and price series was nonlinear with averages larger than their median and mode (Yaya et al., 2017). The series leptokurtic distribution is due to the kurtosis excess of the price of the unshelled and shelled Brazil nuts in relation to their normal distribution (Silva, 2009). This distribution type is common in the series for financial commodities such as crude oil, natural gas, gold and silver (Chkili et al., 2014).

The heteroskedasticity of the price and return series of the Brazil nut is due to the time series variance being dependent on the past with volatility grouped (Engle, 1982) and residual variance not being constant (Seekell et al., 2011), that is, increasing or decreasing linearly, as a function of one or more predictors (Hayes \& Cai, 2007). This indicates that the ARCH family models can shape the conditional variance (volatility) of the series (Engle, 1982; Bollerslev, 1986) .

The parameters $\alpha_{0}, \alpha_{i}$ and $\beta_{j}$ greater than zero and $\sum_{\mathrm{i}=1}^{\mathrm{p}_{1}} \alpha_{i}+\sum_{\mathrm{j}=1}^{\mathrm{q}_{1}} \beta_{i}$ lower than one of the GARCH model indicated result consistency (Bollerslev, 1986). The shock persistence over a long period in the return volatility of the shelled nut is due to records in the return memory (Lee \& Rui, 2001) in the GARCH. Thus, greater will be the process of reverting the mean to the variance (Silva, 2009). The estimated ARCH and GARCH parameter sums of a GARCH model value close to one are common in empirical research, and are considered to be characteristic of persistent volatility (Ding \& Granger, 1996). Time series of returns and stock volatility on four of China stock exchanges have shown strong volatility over time with GARCH and EGARCH model studies, highlighting that volatility is highly persistent and predictable due to evidence of long-term return (Lee \& Rui, 2001). Political, natural, economic, and social events caused structural breaks or periodic sudden changes in financial time series and may have affected shelled nut return series (Tule \& Ndako, 2017). Socioeconomic advances in 2006 in the Brazil nut harvest with participatory mapping, silvicultural techniques and other programs improved its production, making it efficient, and sustained and increasing the local price (Wadt et al., 2008). Rainforest destruction reduces extractivism and impacts the Brazil nut production price (Silva et al., 2013). Changes in the new Brazilian Forest Code in 2012, regulating forest regrowth with native species for environmental suitability (Oliveira Neto et al., 2012), allowed new economic uses for non-timber products, such as Brazil nuts. Therefore, structural breaks in data series can influence GARCH parameter estimation, implying a strong volatility persistence as observed for returns on stock (Lamoureux \& Lastrapes, 1990) and financial assets (Andreou \& Ghysels, 2002).

The volatility parameter $\gamma$ differingfrom zero in the EGARCH model explains the asymmetry in the volatility of shelled nut income (McAleer \& Hafner, 2014). This is due to its flexibility in disaggregating the return volatility impact on cluster effects, asymmetry and shock persistence, allows for determination of the extent of volatility clustering (Elyasiani \& Mansur, 2017). Non-linear moving average process of random coefficients could deliver non-leverage (McAleer \& Hafner, 2014).

The TARCH model identified shock asymmetry by examining the long-term dependence of shelled nut returns and the asymmetric response of volatility over past shocks (long-term memory) (Chen \& Yu, 2005). The leverage effect from longterm volatility has shown that price volatility will increase when values decrease due to bad news, such as a decline in the 
market (Koutmos \& Booth, 1995). Leverage explains that the oil price shock (and oil price volatility), for example, exhibits asymmetric effects in industrial production with a positive and negative differential impact on the economy (Peter Ferderer, 1996). This is also the case in the Brazil nut market, with the expected timing during the year reducing production.

The GARCH model may describe the short-term effects better than the longer-term effects due to different volatility components prevailing over these periods. Some of these components may have a very short-term effect and disappear very quickly, while others have a smaller effect, but which lasts over a longer time period (Ding et al., 1996). The asymmetry in the price series of unshelled nuts was due to different impacts of good and bad information on volatility (Matei, 2009). This shows that the unshelled nut market is still developing, and most investors are more optimistic about expected returns as reported in relation to the Chinese stock market (Yang \& Wu, 2011). The non-linear dependence, that is, when there is conditional heteroscedasticity in the returns of all price series, may explain the high shock persistence (Bhar \& Nikolova, 2009).

The parameter associated with the dummy term differed from zero due to exogenous price interventions, such as political decisions which do not consider the volatility impact (McKenzie, 2002). The negative relationship between volatility and equity (Christie, 1982), the fall in stock values and turbulence in external markets increasing domestic trader volatility expectatives caused the leverage effect. Many traders resist buying and selling earlier according to market volatility, resulting in falling prices by balancing the volume of buying and selling and thus raising the leverage ratio (Wu, 2001) and risk aversion (İnkaya \& Yolcu Okur, 2014).

The TARCH model was an effective tool, simple to use and easy to obtain estimates, reflecting the asymmetric relationship between volatility and past returns (Zakoian, 1994). This model can also easily capture the asymmetry in the return series and is stronger with larger sample sizes (Li \& Lam, 1995). The best EGARCH setting was due to the ease of use of the parameterization of asymmetric effects, where volatility tends to increase and decrease in response to "bad" and "good" news, respectively. In addition, the EGARCH model includes constant, delayed error variables normalized by variance and, of conditional variance (Goyal \& Arora, 2012). This does not impose non-negativity and without ambiguity in interpreting the shock persistence in conditional variation, resolving many of the disadvantages, which characterize the ARCH model structure (Zaffaroni, 2009).

\section{Conclusions}

The international price of both unshelled and shelled Brazil nuts fluctuated over the years with a symmetrical trend, but with price behavior differences between the periods.

The lower risk, volatility, and shock persistence increase the price and return of shelled nuts. The risk of investing in Brazil nuts is high and its return low.

The volatility of Brazil nut prices was high and persistent during the period analyzed. Moreover, volatility responded faster to negative than positive returns, demonstrating the aversion of investors to risks associated with Brazil nut exportation. Therefore, the investment in shelled nuts is more attractive than in unshelled ones, mainly for export.

The GARCH model predicted high volatility in market behavior for unshelled nuts, which remained for several periods. The EGARCH and TARCH models showed differential impacts due to negative and positive shocks in the price and return volatility of Brazil nuts. Past information on Brazil nut prices influenced its price in the present. The main limitation of the study was the difficulty in obtaining updated data on Brazil nut trading.

Studies using ARCH models to determine the volatility and price interrelationship of other NTFPs most exported in Brazil, such as acai palm, cashew nuts, essential oils, vegetable waxes and their interrelationship, can help investors in the 
segment to make decisions. and of policy makers aimed at the forest sector, as price fluctuations impact the sector and influence profitability, employment generation and income in Brazil.

The study of the relationship between economic variables of Brazil nuts and other NTFPs can be carried out through research using multivariate models such as Baba-Engle-Kraft-Kroner (BEKK) and Dinamic Conditional Correlation (DCC).

\section{Acknowledgments}

We thank the "Coordenação de Aperfeiçoamento de Pessoal de Nível Superior (CAPES)" for their financial support. David Michael Miller, a professional editor and proofreader and native English speakinger, has reviewed and edited this article for structure, grammar, punctuation, spelling, word choice, and readability.

\section{References}

Ahenkan, A., \& Boon, E. (2010). Commercialization of non-timber forest products in ghana: processing, packaging and marketing. J. Food, Agric. Environ. 8, 962-969.

Andersen, T. G., Bollerslev, T., Diebold, F. X., \& Ebens, H. (2001). The distribution of realized stock return volatility. J. Financ. Econ. 61, 43-76.

Andersson, M., \& Gong, P. (2010). Risk preferences, risk perceptions and timber harvest decisions — An empirical study of nonindustrial private forest owners in northern Sweden. Forest Policy Econ. 12, 330-339.

Andreou, E., \& Ghysels, E. (2002). Detecting multiple breaks in financial market volatility dynamics. J. Appl. Econ. 17, 579-600.

Angelo, H., Almeida, A. N., Calderon, R. A.,Pompermayer, R. S., \& Souza, Á. N. (2013). Determinantes do preço da castanha-do-brasil (Bertholletia excelsa) no mercado interno brasileiro. Sci. For. 41, 195-203.

Assies, W. (1996). Amazon nuts, forests and sustainability in Bolivia and Brazil. Semin. Proc. 'NFTP Res. Tropenbos Program. Results Perspect. 26, 95-106.

Baquião, A.C., Zorzete, P., Reis, T.A., Assunção, E., Vergueiro, S., \& Correa, B. (2012). Mycoflora and mycotoxins in field samples of Brazil nuts. Food Control. 28, 224-229.

Barak, S., Arjmand, A., \& Ortobelli, S. (2017). Fusion of multiple diverse predictors in stock market. Inform. Fusion. 36, 90-102.

Baroi, G. N., Gavala, H. N., Westermann, P., \& Skiadas, I. V. (2017). Fermentative production of butyric acid from wheat straw: Economic evaluation. Ind. Crops Prod. 104, 68-80.

Bayma, M. M. A., Malavazi, F. W., Sá, C. P., Fonseca, F. L., Andrade, E. P., \& Wadt, L. H. O. (2014). Aspectos da cadeia produtiva da castanha-do-brasil no estado do acre, brasil. Bol. Mus. Para. Emílio Goeldi. Cienc. Nat. 9, 417-426.

BCB - Banco Central do Brasil. (2017). Cotação. http://www4.bcb.gov.br/pec/taxas/port/ ptaxnpesq.asp?id=txcotacao

Belcher, B., \& Schreckenberg, K. (2007). Commercialisation of Non-timber Forest Products: A reality check. Dev. Policy Rev. $25,355-377$.

Bhar, R., \& Nikolova, B. Return, volatility spillovers and dynamic correlation in the BRIC equity markets: An analysis using a bivariate EGARCH framework. (2009). Global Financ. J. 19, 203-218.

Bojnec, Ц̆., \& Fertő, I. (2012). Complementarities of trade advantage and trade competitiveness measures. Appl. Econ. 44, 4, $399-408$.

Bollerslev, T. (1986). Generalized autoregressive conditional heteroskedasticity. J. Econ. 31, 307-327.

Brasil. Ministério do Meio Ambiente. (2017). Castanha-do-Brasil: boas práticas para o extrativismo sustentável orgânico / Ministério do Meio Ambiente. Secretaria de Extrativismo e Desenvolvimento Rural Sustentável. Departamento de Extrativismo. - Brasília, DF: MMA, p.1-55.

Brokamp, G., Valderrama, N., Mittelbach, M., Barfod, A. S., \& Weigend, M. (2011). Trade in palm products in north-western south america. Bot. Rev. 77, $571-606$.

Buckley, P. J., Pass, C. L., \& Prescott, K. (1988). Measures of international competitiveness: A critical survey. J. Mark. Manag. 4, 175-200.

Chen, C. W. S., \& Yu, T. H. K.(2005). Long-term dependence with asymmetric conditional heteroscedasticity in stock returns. Phys. A Stat. Mech. Appl. 2005, $353,413-424$.

Chkili, W., Hammoudeh, S., \& Nguyen, D. K. (2014). Volatility forecasting and risk management for commodity markets in the presence of asymmetry and long memory. Energy Econ. 41, 1-18.

Christie, A. (1982). The stochastic behavior of common stock variances value, leverage and interest rate effects. J. Financ. Econ. 10, 407-432.

Collinson, C., Burnett, D., \& Agreda, V. (2000). Economic viability of Brazil nut trading in Peru. Natural Resources Institute, University of Greenwich, Report 2520, Chatham Maritime, pp. 1-64. 
Coslovsky, S. V. (2014). Economic development without pre-requisites: How bolivian producers met strict food safety standards and dominated the global brazil-nut market. World Dev. 54, 32-45.

Costa, J. R., Castro, A. B. C., Wandelli, E. V., Coral, S. C. T., \& Souza, S. A. G. (2009). Aspectos silviculturais da castanha-do-brasil (Bertholletia excelsa) em sistemas agroflorestais na amazônia central. Acta Amazon. 39, 843-850.

Ding, Z., \& Granger, C. W. J. (1996). Modeling volatility persistence of speculative returns: A new approach. J. Econ. 73, 185-215.

Duchelle, A. E., Cronkleton, P., Kainer, K. A., Guanacoma, G.; \& Gezan, S. (2011). Resource theft in tropical forest communities: Implications for nontimber management, livelihoods, and conservation. Ecol. Soc. 16, 4.

Dwyer, L., Forsyth, P., \& Rao, P. (2000). The price competitiveness of travel and tourism: a comparison of 19 destinations. Tour. Manag.21, 9-22.

Elyasiani, E., \& Mansur, I. (2017). Hedge fund return, volatility asymmetry, and systemic effects: A higher-moment factor-EGARCH model. J. Financ. Stabil. $28,49-65$.

Engle, R. F. (1982). Autoregressive conditional heteroscedasticity with estimates of the variance of united kingdom inflation. Econometrica. 50 , 987.

Enríquez, G. (2010). Amazônia - Rede de inovação de dermocosméticos sub-rede de dermocosméticos na Amazônia a partir do uso sustentável de sua biodiversidade com enfoques para as cadeias produtivas da castanha-do-pará e dos óleos de andiroba e copaíba. Parcerias Estratégicas. 14, 51-118.

Food and Agriculture Organization (FAO). (2017). Available at: http://www.fao.org/home/en/

Geltner, D. M., \& Van De Minne, A.(2017). Do different price points exhibit different investment risk and return in commercial real estate?. The J. Portif. Manag. 43, 105-109.

Goeschl, T., \& Igliori, D. C. (2006). Property rights for biodiversity conservation and development: extractive reserves in the Brazilian amazon. Dev. Change. $37,427-451$.

Goyal, A., \& Arora, S. (2012). The Indian exchange rate and Central Bank action: An EGARCH analysis. J. Asian Econ. $23,60-72$.

Hansen, P. R., \& Lunde, A. (2009). A forecast comparison of volatility models: does anything beat a GARCH(1,1)?. J. Appl. Econom. 20, 873-889.

Hayes, A. F., \& Cai, L. (2007). Using heteroskedasticity-consistent standard error estimators in OLS regression: An introduction and software implementation. Behav. Res. Methods. 39, 709-722.

Helbingen, A. J. B. (2001). Balance is beautiful: assessing sustainable development in the rain forests of the bolivian amazonia. PROMAB scientific series 4: Utrecht, Netherlands. pp. 255.

Homma, O. A. K., Carvalho, R. de A., Ferreira, C. A. P., \& Júnior, J. de D. B. N. A destruição dos recusros naturais: o caso da castanha-do-pará no sudeste paraense. In: Proceedings of the Anais do Encontro da Sociedade Brasileira de Economia Ecológica; 2001; p. 1-25.

Ingram, V., Ndoye, O., Iponga, D. M., Tieguhong, J. C., \& Nasi, R. (2012). The Non-timber forest products: contribution to national economy and strategies for sustainable management. In: de Wasseige, C., de Marcken, P., Bayol, N., Hiol, F.H., Mayaux, P., Desclée, B., Nasi, R., Billand, A., Defourny, P., Eba'a,

R. (Eds.). Forests of the Congo Basin. State of the Forest. Office des publications de l'Union Européenne, Luxembourg, p. 276.

,İnkaya, A., \& Yolcu Okur, Y. (2014). Analysis of volatility feedback and leverage effects on the ISE30 index using high frequency data. J. Comput. Appl. Math. 259, 377-384.

Instituto Brasileiro de Geografia e Estatística (IBGE). (2017). Quantidade produzida e valor da produção na extração vegetal, por tipo de produto extrativo Available at: https://sidra.ibge. gov.br/tabela/289 (

INPE - Instituto Nacional de Pesquisas Espaciais. (2016). PRODES estima 7.989 km2 de desmatamento por corte raso na Amazônia em 2016. http://www.inpe.br/ noticias/noticia. php?Cod__Noticia $=4344$

Jubert, R. W., Monte, P. A., Paixão, M. C. S., Lima, W. H. (2008). Um estudo do padrão de volatilidade dos principais índices financeiros do Bovespa : uma aplicação de modelos Arch. Rev. Contabil. Gestão e Gov. 11, 221-239.

Kainer, K. A., Wadt, L. H. O., \& Staudhammer, C. L. (2007). Explaining variation in Brazil nut fruit production. Forest Ecol. Manag. $250,244-255$.

Kalliola, R., \& Flores, P. (2011). Brazil nut harvesting in peruvian amazonia from the perspective of ecosystem services. Fennia. 189,1-13.

Koutmos, G., \& Booth, G. G. (1995). Asymmetric volatility transmission in international stock markets. J. Int. Money Financ. 14, 747-762.

Lamoureux, C. G., \& Lastrapes, W. D. (1990). Persistence in variance, structural change, and the GARCH model. J. Bus. Econ. Stat. 8, 225.

Langley, S. V., Giugale, M., Meyers, W. H., \& Hallahan, C. (2000). International financial volatility and agriculturalcCommodity trade: A primer. Am. J. Agric. Econ. 82, 695-700.

Lantz, V. Measuring scale, technology and price effects on value-added production across Canadian forest industry sectors. Forest Policy Econ. 2005, 7, 333344.

Lee, C. F., Chen, G., \& Rui, O. M. (2001). Stock returns and volatility on china's stock markets. J. Financ. Res.24, 523-543.

Li, W. K. \& Lam, K. (1995). Modelling asymmetry in stock returns by a threshold autoregressive conditional heteroscedastic model. Statistician. 44, 333. 
MAPA, 1976. Portaria No 846 sobre padronização, classificação e comercialização interna da Castanha do Brasil. Diário Oficial No 846, Brasília-DF, 8-111976.

Marius, M. A. (2012). Contribution to multivariate volatility modeling with high frequency data. Doctoral Thesis, Departament Economia, Ciències Socials i Mètodes Universitat Ramon Llull, 2012.

Matei, M. (2009). Assessing volatility forecasting models: Why GARCH models take the lead. Rom. J. Econ. Forecast. 12, 42-65.

McAleer, M., \& Hafner, C. (2002). A one line derivation of EGARCH. Econometrics 2014, 2, 92-97

McKenzie, M. The economics of exchange rate volatility asymmetry. Int. J. Financ. Econ. 7, 247-260.

MDIC consultas. (2016) http://comexstat.mdic.gov.br/pt/home/.

Monteiro, L. de M., Nogueira, R. M., \& Pires, E. M. (2016). A valid method for determining the water content of the Brazil nut (Bertholletia excelsa). Biosci. J. 952-959.

Montgomery, D. C., Peck, E. A., \& Vining, G. G. (2012). Introduction to Linear Regression Analysis.; John Wiley \& Sons, Org.; John Wiley \& Sons. 821.

Morettin, P. A., \&Toloi, C. M. C. (2006). Análise de séries temporais, 2nd ed; Edgard Blücher: São Paulo,Brasil. pp. 538.

Mugido, W., \& Shackleton, C. M. (2018). Price determination of non-timber forest products in different areas of south africa. Ecol. Econ. 146, 597-606.

Nelson, D. B. (1991). Conditional heteroskedasticity in asset returns: a new approach. Econometrica. 59, $347-370$.

Nelson, V., Galvez, M., \& Blowfield, M. (2000). Social impact of ethical and conventional Brazil nut trading on forest-dependent people in Peru. Natural Resources Institute, University of Greenwich, Chatham Maritime. Pp. 46.

Noce, R., Silva, M. L. da, Mendes, L. M., Souza, A. L. de, Rezende, J. L. P. de; Carvalho, R. M. M. A., Canto, J. L. do, \& Oliveira, J. M. de. (2010). Relationship risk-return of native species sawn wood in the state of Pará, Brazil 2003-2007. Cerne. 16, $199-207$.

Oliveira Neto, S. N., Lana, V. M., \& Costa, C. B. V. M. (2012). Sistemas agroflorestais para adequação ambiental de propriedades rurais. Inf. Agropecuário. $33,70-78$.

Otuki, T. F., Weydmann, C. L., \& Seabra, F. ()2009. Febre aftosa e volatilidade dos preços do produtor de carne suína. Rev. Econ. e Agron. 7, $235-258$.

Pacheco, A., \& Scussel, V. (2009). Aflatoxins evaluation on in-shell and shelled dry brazil nuts for export analysed by lc-ms/ms - 2006 and 2007 harvests. World Mycotoxin J. 2, 295-304.

Pacheco, A. M., \& Martins, M. (2013). Brazil nut sorting for aflatoxin prevention: a comparison between automatic and manual shelling methods. Food Sci. Technol. 33, 369-375.

Peter Ferderer, J. (1996). Oil price volatility and the macroeconomy. J. Macroecon. 18, 1-26.

Purcell, W. D., \& Koontz, S. R. (1999). Agricultural futures and options: Principles and strategies, 2nd ed; Prentice Hall, Upper Saddle River: New Jersey, United States. pp.645.

Rabadán, A., González-Moreno, Á., Sáez-Martínez, F. J. (2019). Improving firms’ performance and sustainability: The case of eco-innovation in the agri-food Industry. Sustainability. 11, 5590.

Reis, T. A., Baquião, A. C., Atayde, D. D., Grabarz, F., \& Corrêa, B. (2014). Characterization of Aspergillus section Flavi isolated from organic brazil nuts using a polyphasic approach. Food Microbiol. 42, 34-39.

Riguero, A., Fernández, S., \& Sáez-Martinez, F. J. (2018). Inbound open innovative strategies and eco-innovation in the Spanish food and beverage industry. Sustain. Prod. Consum. 15, 49-64.

Ros-Tonen, M. A. F., Van Andel, T.,Morsello, C., Otsuki, K., Rosendo, S., \& Scholz, I. (2008). Forest-related partnerships in Brazilian Amazonia: There is more to sustainable forest management than reduced impact logging. Forest Ecol. Manag. 256, 1482-1497.

Sabiruzzaman, M., Huq, M. M., Beg, R. A., \& Anwar, S. (2010). Modeling and forecasting trading volume index: GARCH versus TGARCH approach. The Quart. Rev. Econ. Financ. 50, 141-145.

Santos, S. J. P. (2003). Um estudo de eficiência de mercado usando séries temporais com diferenciação fracionária: o caso de commodities agrícolas. Doctoral Thesis, Departamento de Economia- Universidade Federal de Pernambuco, Recife. pp. 103.

Sardeshpande, M., \& Shackleton, C. (2019). Wild edible fruits: a systematic review of an under-researched multifunctional NTFP (Non-Timber Forest Product). Forests. 10, 1-467.

Sathre, R., \& Gustavsson, L. (2009). Process-based analysis of added value in forest product industries. Forest Policy Econ. 11, 65-75.

Schirigatti, E. L., Aguiar, G. P., Silva, J. C. G. L., Frega, J. R., Almeida, A. N., \& Hoeflich, V. A. (2016). Market behavior for in shell brazil nuts produced in Brazil from 2000 to 2010. Floresta e Ambiente. 23, 369-377.

Scoles, R., \& Gribel, R. (2011). Population structure of brazil nut (Bertholletia excelsa, Lecythidaceae) stands in two areas with different occupation histories in the brazilian amazon. Hum. Ecol.39, 455-464. 
Scussel, V. M., Giordano, B. N., Simao, V., Manfio, D., Galvao, S., \& Rodrigues, M. N. F. (2011). Effect of oxygen-reducing atmospheres on the safety of packaged shelled Brazil nuts during storage. Int. J. Anal. Chem. 2011, 1-9.

Seekell, D. A., Carpenter, S. R., \& Pace, M. L. (2011). Conditional heteroscedasticity as a leading indicator of ecological regime shifts. Am. Nat. 178, 442451.

Shanley, P., Silva, M. S., Melo, T., Carmenta, R., \& Nasi, R. (2012). From conflict of use to multiple use: forest management innovations by small holders in amazonian logging frontiers. Forest Ecol. Manag. 268, 70-80.

Siggel, E. (2006). International competitiveness and comparative advantage: A survey and a proposal for measurement. J. Ind. Compet. Trade. 6, 137-159.

Silva, A. A., Santos, M. K. V., Gama, J. R. V., Noce, R., \& Leão, S. (2013). Potencial do extrativismo da castanha-do-Pará na geração de renda em comunidades da mesorregião baixo Amazonas, Pará. Floresta e Ambiente. 20, 500-509.

Silva, C. A. G. (2009). Modelagem de estimação da volatilidade do retorno das ações brasileiras:os casos da Petrobras e Vale. Cad. do ime - Série Estatis. 26, $1-15$.

Silva, C. A. G., \& Ferreira, L. D. R. (2015). Long-memory presense in the volatility of fat ox daily prices in brazil of fat ox daily prices in Brazil. Int. J. Res. Soc. Sci. 4, 48-55.

Silvertown, J. Sustainability in a nutshell. Trends Ecol. Evol. 2004, 19, 276-278.

Soares, N. S., \& Silva, M. L. (2010). Competitividade brasileira no comércio internacional de produtos extrativos vegetais. Rev. Econ. Nordeste. 44, 879-893.

Soriano, M., Mohren, F., Ascarrunz, N., Dressler, W., \& Peña-Claros, M. (2017). Socio-ecological costs of amazon nut and timber production at community household forests in the bolivian amazon. PloS One. 12, 1-25.

Stoian, D.(2005). Making the best of two worlds: rural and peri-urban livelihood options sustained by nontimber forest products from the bolivian amazon. World Dev. 33, 1473-1490

Stoian, D. (2000). Shifts in forest product extraction: the post-rubber era in the bolivian amazon. Int. Tree Crop. J. 10, $277-297$.

Stoian, D., \& Henkemans, A. B. (2000). Between extractivism and peasant agriculture: differentiation o rural settlements in the bolivian amazon. Int. Tree Crop. J. 10, 299-319.

Toledo, R. A., Gomes, C. S., \& Palmieri, R. (2016). Panorama nacional da cadeia de valor da castanha-do-Brazil; Instituto de Manejo e Certificação Florestal e Agrícola (IMAFLORA): São Paulo. pp. 60.

Tonini, H., \& Pedrozo, C. A. (2014). Variações anuais na produção de frutos e sementes de de castanheira - do - brasil (Bertholletia excelsa Bonpl., Lecythidaceae) em florestas nativas de roraima. Rev. Arv. 38, 133-144.

Tule, M. K., Ndako, U. B., \& Onipede, S. F. (2017). Oil price shocks and volatility spillovers in the Nigerian sovereign bond market. Rev. Financ. Econ. 35, $57-65$.

Turtiainen, M., \& Nuutinen, T. (2012). Evaluation of information on wild berry and mushroom markets in european countries. Small-Scale For. 2012, 11, $131-145$.

Wadt, L. H. O., Kainer, K. A., Staudhammer, C. L., \& Serrano, R. O. P. (2008). Sustainable forest use in Brazilian extractive reserves: Natural regeneration of Brazil nut in exploited populations. Biol. Conserv. 141, 332-346.

Wu, G. (2001). The determinants of asymmetric volatility. Rev. Financ. Stud. 14, 837-859.

Yang, H., \& Wu, X. (2011). Semiparametric EGARCH model with the case study of China stock market. Econ. Model. 28, 761-766.

Yang, J. (2009). Brazil nuts and associated health benefits: a review. Lwt - Food Sci. Technol. 42, 1573-1580.

Yaya, O. S., Akinlana, D. M., \& Shittu, O. I. (2017). Modelling Nigerian Banks' share prices using smooth transition GARCH models. CBN J. Appl. Stat. 7, $137-158$.

Zaffaroni, P. (2009). Whittle estimation of EGARCH and other exponential volatility models. J. Econometrics. 151, 190-200.

Zakoian, J. M. (1994). Threshold heteroskedastic models. J. Econ. Dyn. Control. 18, 931-955.

Zuidema, P. A. (2003). Demography and management of the brazil nut tree (Bertholletia excelsa). PROMAB Scientific series 6: Utrecht,Netherlands. pp.1113. 